\title{
Histomorphometric alterations of muscle soleus provoked by drawn out immobilization: experimental study with wistar lineage rats
}

\author{
Alterações histomormofétricas do músculo sóleo \\ provocadas pela imobilização prolongada: estudo \\ experimental com ratos da linhagem wistar
}

Priscila Daniele de Oliveira ${ }^{[a, b]}$, Célia Regina de Godoy Gomes ${ }^{[c]}$, Rodrigo Franco de Oliveira ${ }^{[b]}$, Deise A. de Almeida Pires-Oliveira ${ }^{[b]}$, Sonia Maria Marques Gomes Bertolini ${ }^{[c, d] *}$

[a] Universidade Estadual de Londrina (UEL), Londrina, PR, Brazil
[b] Universidade Norte do Paraná (Unopar), Londrina, PR, Brazil
[c] Universidade Estadual de Maringá (UEM), Maringá, PR, Brazil
[d] Centro Universitário de Maringá (Cesumar), Maringá, PR, Brazil

\section{Abstract}

Objective: This study has as objective to analyze the effect of joint immobilization of the soleus muscle of posterior members of rats on morphometric profile view, at periods of 21 and 45 days. Materials and methods: Ten male Rattus novergicus albinus, Wistar variety, were used, separated into two groups (group

* PDO: MSc, e-mail: prisciladanielefisio@hotmail.com CRGG: PhD, e-mail: fedora-30@hotmail.com RFO: PhD, e-mail:rfrancoli@yahoo.com.br DAAPO: PhD, e-mail: deisepyres@yahoo.com.br SMMGB: PhD, e-mail: smmgbertolini@uem.br 
I and II), of 5 animals each, with the first group submitted to immobilization for 21 days and the second for 45 days. The experiment control was acquired from the right contralateral member of each animal. The immobilization of the left posterior member was done by adapted orthesis. The morphometric analysis of soleus was by non-serial cross sections, $8 \mu \mathrm{m}$ thick. Results: From the obtained images, the muscle fibers areas were analyzed, including the form of the fibers, comparing with the control group. In both the periods of immobilization cross sections of staple fibres had reduction of the section area, front to the comparison to its respective member has controlled, with significant important $(p<0.0001)$, especially it enters the experimental groups of 21 and 45 days. Conclusion: It can be concluded that immobilization to articulate of rats per 21 and 45 days modifies the section area more transversa of staple fibres of the sóleo muscle and deleterious effect of more significant the cellular components for drawn out periods.

Keywords: Immobilization. Rats. Skeletal muscle.

\section{Resumo}

Objetivo: Este estudo teve como objetivo verificar os efeitos da imobilização articular no músculo sóleo de ratos, por meio de uma análise histomorfométrica, em períodos de 21 e 45 dias. Materiais e métodos: Foram utilizados 10 Rattus novergicus albinus machos, variedade Wistar (3 a 4 meses, massa corpórea entre 250-300 g). A amostra foi dividida em dois grupos (G1 e G2), com 5 animais em cada, sendo o primeiro grupo submetido à imobilização por 21 dias e o segundo por 45 dias. 0 controle do experimento foi obtido a partir do membro contralateral direito do respectivo animal. A imobilização do membro posterior esquerdo foi feita por meio de uma órtese adaptada. A análise histomorfométrica do sóleo foi realizada por meio de cortes transversais não seriados de 8 um de espessura. Resultados: Foram analisadas, por meio das imagens obtidas, a forma e a área das fibras musculares comparando-as com o grupo-controle. Foi observada a presença de fibras musculares com morfologias distintas, evidenciadas pelos diferentes contornos celulares, predominando fibras com formato poliédrico. Em ambos os períodos de imobilização houve redução da área de seç̧ão transversa das fibras, frente à comparação ao seu respectivo membro contralateral, com diferenças significativas ( $p<0,0001)$, especialmente entre os grupos experimentais. Conclusão: Pode-se concluir que a imobilização articular de ratos por 21 e 45 dias altera a área de secção transversa das fibras do músculo sóleo, sendo as alterações mais significativas evidenciadas em períodos mais prolongados de restrição ao movimento.

Palavras-chave: Imobilização. Ratos. Músculo esquelético.

\section{Introduction}

Generally, in the clinical practice it is observed a tendency to precocious immobilization of a body segment $(1,2)$ due to orthopedic or neurological affections, such as ligament ruptures, fractures and muscle lesions $(3,4)$.

The immobilization of a body segment comprehends local rest, continuous and rigid (5) with morphological, physiological and biochemical manifestations in the skeletal musculature $(6,7,8,9,10)$ observed in animals (11) as well in human beings (12).

The restriction to movement by immobilization, because of its non-contribution to homeostatic maintenance in anabolic and catabolic reactions, converges to alterations of trophic character (4), and, yet can be distinguished by the strength decreasing, by the muscle size, the fiber area (13), the extensibility (14), the resistance of ligaments and tendons, contracture formation, electrical activity alteration (15) and reduction of the number of sarcomeres in series resulting in muscle rigidity during the first week of immobilization (16).

In this sense, Gomes et al. (17) add that the muscle disuse also promotes the decrease in the density of capillaries and the spreading of the intramuscular connective tissue both in the perimysium and in the endomysium, besides promoting an increasing of collagen fibers of the tissue (18), reduction of glycogen reserves, increase in fatigability (19), decrease in 
size and number of mitochondria, increase in lactate concentration with the work (20) and lastly, skeletal muscle hypertrophy $(19,21)$.

According to Appel (22) and Glass (23), hypertrophy may be defined as a consequence of the subtraction in the muscle protein synthesis and/or development of it, and the decrease of availability of energetic substrates. Taking into account that the causes are distinguished among age, gender, muscle group (extensor/flexor), fiber type, length, immobilization time and position in which the muscle is immobilized (22).

Caiozzo et al. (24) and Lieber (25) reinforce that uniarticulate muscles, whose action is anti-gravity, have a higher degree of hypertrophy in situations of disuse. Simultaneously, Kasper et al. (26) and Talmadge (27) observe that fibers of type I have a better adaptability in relation to fibers of type II, being, therefore, more affected, which makes it possible to confirm that the soleus muscles that are mainly constituted of tonic fibers suffer considerable compromising regards mobility restriction (28).

In experimental range, some studies were directed to the different periods of muscle inactivity, showing that, only one week is enough to promote important sarcomeres adaptations and morphometric alterations in the mechanism of soleus muscles and gastrocnemius of rats $(2,6,18,29,30,31)$. In this sense, there are researches that show a reduction of almost 23\% of reduction of the gastrocnemius muscle diameter in immobilizations for 14 days $(21,32)$ or 21 (33).

The literature points out atrophy by immobility varying from $15 \%$ to $70 \%$ (34) and along two months, a normal muscle may lose up to half of its volume (35).

According to these reports and considering that immobilization is still an option of treatment frequently used, although it brings undesirable deleterious effects to the muscle fibers (36) directly influencing musculoskeletal lesions rehabilitation, this study had as an objective verifying the effects of articular immobilization in soleus muscles from rats, through histomorphometric analysis in periods of 21 and 45 days.

\section{Materials and methods}

The present study received approval from the Committee for Ethical Conduct in Animal
Experimentation of the Universidade Estadual de Maringá (CEAE), report 011/2009. A total of 10 male Rattus navergicus albinus, Wistar variety (three to four months, body mass between 250-300 g). They were divided into two groups (groups I and II), five animals each, the first group underwent immobilization for 21 days and the second one for 45 days. The control of the experiment was made through the right contralateral limb of the animal.

The animals stayed at Centro Universitário de Maringá (Cesumar) animal house being treated according to the recommendations from Guide for the care and use of laboratory animals (37), where they stayed in polypropylene cages $(39 \mathrm{~cm}$ length $\times 32 \mathrm{~cm}$ width x $16 \mathrm{~cm}$ height), covered with wood shaves. The environment was acclimatized and controlled to periodic photo cycles 12 hours light/dark, with water and rat food (Purina ${ }^{\mathrm{TM}}$ for rodents) ad libitum. The general monitoring of the experimented member happened daily.

The animals were anaesthetized with an anesthetic association of Ketamine at $50 \mathrm{mg} / \mathrm{kg}^{-1} \mathrm{com}$ bined with $10 \mathrm{mg} / \mathrm{kg}^{-1}$ Xylazine, with the dose of $0.1 \mathrm{~mL}$ for each $100 \mathrm{~g}$ of weight, so that the animals were deeply sedated for the realization of the left posterior member immobilization. This, through a molded aluminum orthosis to the segment to be immobilized in $90^{\circ}$ ankle dorsal extension and flexion (38) which permitted the ambulation with weight unloading. This way, when necessary, it was replaced, respecting our procedure. The immobilization didn't stop the load locomotion with weight unload and the animals feeding inside the cage.

After the experimental period, the animals were sacrificed, according to the immobilization phases, with a lethal dose of thiopental sodium $45 \mathrm{mg} / \mathrm{kg} \mathrm{(1g)}$ diluted in water (22 $\mathrm{mL}$ ), applied via intraperitoneal. After that, the dissection of soleus muscle occurred for histological verification.

For histomorphometric analysis, the soleus muscle was withdrawn, being careful so it was possible to maintain the muscle fibers longitudinally disposed in relation to the biggest axis of the fragment, and frozen in liquid nitrogen, following the frozen method of non-fixed tissues (39), for posterior freezer store $\left(-80^{\circ} \mathrm{C}\right)$. Each muscle fragment was withdrawn and subjected to microtomy at $-20^{\circ} \mathrm{C}$ (Leica CM 1985 cryostat $^{\mathrm{TM}}$ ), $\mu \mathrm{m}$ of thickness, they were flushed with hematoxylin/eosin (HE) and fixed with Permont resin. 
After the blade preparation, the observation was auxiliated by Olympus BX40 microscope and obtained in photomicroscope BX50, with photographic equipment PM10-AK. Areas of transverse section of 120 soleus muscle fibers by animal were analyzed, thus determined: 10 fibers by field, being 3 fields by cut, and 4 by animal, in a way which were evaluated the shape and the muscle fiber area $(40,41,42)$.

Both groups were analyzed through the method of average measurement of larger and smaller diameters by Image Pro-Plus 4.5 with objective of $10 \mathrm{X}$ (43). To statistical analysis the $t$ test of Student, with significance level of $5 \%$.

\section{Results}

It was observed in the controlled group the presence of muscle fibers with polygon outlines and regular fascicular pattern (Figures 1A and 1C). It was observed in the experimental group the presence of distinct outlines (polymorphism) of muscle fibers from soleus muscle. It was verified in this group the rounding and diameter decrease of muscle fibers, as well as the increase of the space occupied by endomysium and perymisium demonstrating a clear increase in the occupied area by the connective tissue (Figures 1B and 1D).
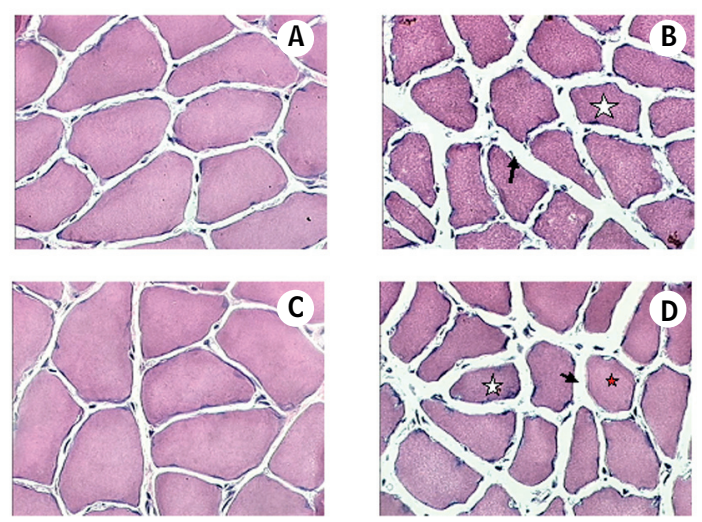

Figure $\mathbf{1}$ - Photomicroscopes of transverse sections of the middle third from the soleus muscle

Note: A: control group; B: experimental group 21 days; C: control group; D: experimental 45 days. Observe reduction of the muscle fibers area (star), increase of connective tissue (arrow) and rounding (red arrow) of fibers in relation to the control group (HE - magnitude of 320x).
Concerning the histomorphometric analysis, in both periods of immobilization there was a reduction of the transverse section of the fibers under the avarege calculation of larger and smaller diameters in relation to the comparison to its respective contralateral member (control). This decrease was of $63.8 \%$ (38.82 \pm 3.86$)$ and of $66.8 \%(41.65 \pm 3.95)$ in the animals of 21 and 45 days of immobilization, respectively. The values were verified by statistic tests with significant importance ( $p<0.0001)$. It is important to emphasize the observation $(p<0.0001)$ of significant importance among the experimental groups of 21 and 45 days, suggesting the progressive exacerbation of hypertrophic degree (muscle volume) when related to the immobilization time (Table 1).

\section{Discussion}

The findings of experimental models done so far do not converge to a general agreement referring to the physiological-histochemical alterations provoked by the muscle disuse, having contradictory conclusions. These denote differential percentage of susceptibility to hypertrophy antagonistic functional equivalence in relation to each type of muscle fiber and its specific location $(1,4,8,16,21)$.

The soleus muscle composed of $84 \%$ of fibers of type I was used for being a biarticular muscle and for acting in static posture as dynamic creating tensile and compressive strength in knees and ankle articulations.

The results of the present study point out the existent association between the transverse area of the muscle fiber and the articular immobilization, during 21 and 45 days. Järvinen et al. (44) report that the longer the exposure period, the bigger the number of collagen deposit between the muscle fibers and the reduction of myofibril volume, interfering in the muscle regeneration process and consequently in the rehabilitation. At articular level, this tissue increase conjunct reduces the articular amplitude of movement, which is harmful to synovial fluid production, therefore the articulation lubrication and the nutrition of articular cartilage. The results reached with the histomorphometric analysis show and increase in the occupied space by the endomysium and perymisium from the animals from the experimental group from 21 and 45 days. 
Table 1 - Average and standard deviation of the transverse section area (in micrometers) of the analyzed fibers from the soleus muscle from the analyzed animals (groups: control and experimental) and value of $p$

\begin{tabular}{cccc}
\hline Experimental period & Control group $(\mathbf{n}=\mathbf{5})$ & Experimental group $(\mathbf{n}=5)$ & $\mathbf{p}^{*}$ \\
\hline 21 days & $60.83 \pm 1.79$ & $38.82 \pm 3.86$ & $<0.001$ \\
45 days & $62.31 \pm 2.87$ & $41.65 \pm 3.95$ & $<0.001$ \\
\hline
\end{tabular}

Note: *t test significant to comparison of the average.

As well as Chakravarthy et al. (45) that demonstrated a significant reduction of soleus muscle mass after three weeks of immobilization and Mercier et al. (3) emphasized that through the suspension of weight unloading, there is a reduction of $40 \%$ in the soleus muscle weight in the same period. In a study from 2004 (46) the authors point out a muscle weight reduction of $33.87 \%$ in the soleus and of $15.08 \%$ in the long finger extensors during the period of 45 days of articular restriction.

Chingui et al. (47) in their studies conclude that the biggest homeostatic compromising occurs in the initial phase of disuse. In this context, it is important to enhance that the determination of the results of studies on immobilization present a multifactorial factor differing regarding the model and used material to promote disuse, the period of immobilization, the articular position and the type of muscle fibers analyzed $(27,28,30,36)$.

Similar to the observation of other authors (48) in the studied samples, we found morphological alterations (presence of diverse outlines of the muscle fibers) and the sharp decline of the muscle fibers diameters after 21 days of immobilization, which corroborates with the findings, Okita et al. (19), Järvinen et al. (49) and Itai et al. (50) report about hypertrophy in the period of three, five and eight weeks, respectively.

As a limitation of the study, we point out the control of the experiment made through right contralateral member from the respective animal, which may have interfered in the movement of the control group initial phase after immobilization.

\section{Conclusion}

The articular immobilization of rats for 21 and 45 days alters the transverse section area of the soleus muscle fibers, in other words, it provokes cellular hypertrophy with significant deleterious effects of cellular components. It is also concluded that the increase of the area of the intermuscular septum indicate a proliferation of the connective tissue of muscle covering and that the biggest alterations are found in the muscle fibers of rats' immobilization for a longer period.

It is suggest experiment studies with group control composed of samples regardless the experimental group.

\section{References}

1. Caierão QM, Teodori R, Minamoto VB. A influência da imobilização sobre o tecido conjuntivo muscular: uma revisão. Fisioter Mov. 2007;20(3):87-92.

2. Lima SC, Caierão QM, Durigan JLQ Schwarzenbeck A, Silva CA, Minamoto VB, et al. Short-term immobilization causes morphometric and mechanical alterations on rat muscles. Rev Bras Fisioter. 2007;11(4):297-302.

3. Mercier J, Perez-Martin A, Bigard X, Ventura R. Muscle plasticity and metabolism: effects of exercise and chronic diseases. Mol Aspects Med. 1999;20(6):319-73.

4. Delfino GB, Durigan JLQ, Cancelliero KM, Silva CA. Efeito do sulfato de vanadil sobre o comprometimento metabólico muscular induzido pela imobilização de membro posterior de ratos. Rev Bras Med Esporte. 2006;12(6):23-8.

5. Abdalla DR, Bertoncello D, Carvalho LC. Avaliação das propriedades mecânicas do músculo gastrocnêmio de ratas imobilizado e submetido à corrente russa. Fisioter Pesqui. 2009;16(1):59-64.

6. Zarzhevsky N, Coleman R, Volpin G, Fuchs D, Stein H, Reznick AZ. Muscle recovery after immobilisation by external fixation. J Bone Joint Surg Br. 1999; 81(5):896-901. 
7. Coutinho EL, Gomes AR, França CN, Salvini TF. A new model for the immobilization of the rat hind limb. Braz J Med Biol Res. 2002;35(11):1329-32.

8. Arruda EJ, Grassi DO, Guirro RRJ, Silva CA. Perfil quimiometabólico de músculos esqueléticos de ratos submetidos a diferentes modelos de imobilização articular. In: Anais da 6. Mostra Acadêmica e do 16. Congresso de Iniciação Científica; Set 2008; Piracicaba. Pracicaba: Unimep; 2008. p. 1-5.

9. Konno EAB, Alves EPB, Bertolini GRF, Barbieri CH, Mazzer N. Remobilização por alongamento estático cíclico em músculo sóleo de ratos imobilizados em encurtamento. Rev Bras Med Esporte. 2008;14(2):122-5.

10. Portinho D, Boin VG, Bertolini GRF. Efeitos sobre o tecido ósseo e cartilagem articular provocados pela imobilização e remobilização em ratos Wistar. Rev Bras Med Esporte. 2008;14(5):408-11.

11. Millis DL. Responses of musculoskeletal tissues to disuse and remobilization. In: Millis DL, Levine D, Taylor RA, editors. Canine rehabilitation \& physical therapy. Missouri: Elsevier; 2004. p. 113-159.

12. Freitas CLR, Rocha CS, Vaz MA. Comportamento mecânico do músculo esquelético após duas semanas de imobilização. In: Anais do 12. Congresso Brasileiro de Biomecânica; 2007; São Pedro. São Pedro: Sociedade Brasileira de Biomecânica; 2007. p. 32-36.

13. Appell HJ. Skeletal muscle atrophies during immobilization. Int J Sports Med. 1986;7(1):1-5.

14. Jackman RW, Kandarian SC. The molecular basis of skeletal muscle atrophy. Am J Physiol Cell Physiol. 2004;287(4):C834-43.

15. Kaplan SJ. Post-hospital home health care: the elderly's access and utilization [dissertation]. St. Louis: Washington University; 1995.

16. Coutinho EL, Gomes ARS, França CN, Oishi J, Salvini TF. Effect of passive stretching on the immobilized soleus muscle fiber morphology. Braz J Med Biol Res. 2004;37(12):1853-61.

17. Gomes ARS, Coutinho EL, França CN, Polonio J, Salvini TF. Effect of one stretch a week applied to the immobilized soleus muscle on rat muscle fiber morphology. Braz J Med Biol Res. 2004;37(10):1473-80.
18. Okita M, Yoshimura T, Nakano J, Motomura M, Eguchi K. Effects of reduced joint mobility on sarcomere length, collagen fibril arrangement in the endomysium, and hyaluronan in rat muscle. J Muscle Res Cell Motil. 2004;25(2):159-66.

19. Reardon KA, Davis J, Kapsa RM, Choong P, Byrne E. Myostatin, insulin-like growth factor-1, and leukemia inhibitory factor mRNAs are upregulated in chronic human disuse muscle atrophy. Muscle Nerve. 2001;24(7):893-9.

20. Krivickas LS. Treinamento de flexibilidade. In: Frontera WR, Dawson DM, Slovir DM. Exercício físico e reabilitação. Porto Alegre: Artmed; 2001. p. 95 -113.

21. Bodine SC, Latres E, Baumhueter S, Lai VK, Nunez L, Clarke BA, et al. Identification of ubiquitin ligases required for skeletal muscle atrophy. Science. 2001;294(5547):1704-8.

22. Appell HJ. Muscular atrophy following immobilization: a review. Sports Med. 1990;10(1):42-58.

23. Glass DJ. Signaling pathways that mediate skeletal muscle hypertrophy and atrophy. Nat Cell Biol. 2003; 5(2):87-90.

24. Caiozzo VJ, Haddad F, Baker MJ, Henrrick RE, Pritto N, Baldwin KM. Microgravity-induced transformations of myosin isoforms and contractile properties of skeletal muscle. J Appl Physiol.1996;81(1):123-32.

25. Lieber RL. Skeletal muscle structure, function, and plasticity, the physiological basis of rehabilitation. 2nd ed. Philadelphia: Lippincott; 2002.

26. Kasper CE, Talbot LA, Gaines JM. Skeletal muscle damage and recovery. AACN Clin Issues. 2002;13(2): 237-47.

27. Talmadge RJ. Mechanical properties of rat soleus after long-term spinal cord transection. J Appl Physiol. 2002;93(4):1487-97.

28. Tanaka T, Kariya Y, Hoshino Y. Histochemical study on the changes in muscle fibers in relation to the effects of aging on recovery from muscular atrophy caused by disuse in rats. J Orthop Sci. 2004;9(1):76-85.

29. Mercier C, Jobin J, Lépine C, Simard C. Effects of hindlimb suspension on contractile properties of young and old rat muscles and the impact of electrical stimulation on the recovery process. Mech Ageing Dev. 1999;106(3):305-20. 
30. Silva CA, Guirro RRJ, Polacow MLO, Cancelliero KM, Durigan JL. Rat hindlimb joint immobilization with acrylic resin orthoses. Braz J Med Biol Res. 2006; 39(7):979-85.

31. Matheus JPC, Gomide LB, Oliveira JGP, Volpon B, Shimano AC. Efeitos da estimulação elétrica neuromuscular durante a imobilização nas propriedades mecânicas do músculo esquelético. Rev Bras Med Esporte. 2007;13(1):55-9.

32. Picquet F, Falempin M. Compared effects of hindlimb unloading versus terrestrial deafferentation on muscular proprieties of the rat soleus. Exp Neurol. 2003;182(1):186-94.

33. Carvalho CMM, Shimano AC, Volpon JB. Efeitos da imobilização e do exercício físico em algumas propriedades mecânicas do músculo esquelético. Rev Bras Eng Biomed. 2002;18(2):65-73.

34. Qin L, Appell HJ, Chan KM, Maffulli N. Electrical stimulation prevents immobilization atrophy in skeletal muscle of rabbits. Arch Phys Med Rehabil. 1997;78(5):512-7.

35. Choniac R, Videira, RVS, Ruiz SAL. Atrofia muscular em pacientes oncológicos internados em unidade de terapia intensiva. Rev Fisioter Univ São Paulo. 2004; 2(11):77-82.

36. Sakakima H. Effects of immobilization and subsequent low and high frequency treadmill running on rat soleous muscle and ankle joint movement. J Phys Ther Sci. 2004;16(1):43-8.

37. Clark D, Barthold SW, Bayne KA, Davis MA, Everitt JI, Fox JG. Guide for the care and use of laboratory animals. 3rd ed. Washington: National Academy Press; 1997.

38. Bertolini SMMG, Oliveira PD, Cararo DC. Estudo morfométrico do músculo sóleo de ratos da linhagem wistar pós-imobilização articular. Acta Sci Health Sci. 2009;31(1):15-18.

39. Dal-Pai V. Histoenzimologia: teoria e prática. Botucatu: Instituto de Biociências - Unesp; 1995.

40. Fridén J, Liber RL. Structural and mechanical basis of exercise-induced muscle injury. Med Sci Sports Exerc. 1992;24(5):521-30.

41. Antonio J, Gonyea WJ. Skeletal muscle fiber hyperplasia. Med Sci Sports Exerc. 1993;25(12):1333-45.
42. Sartori JR, Gonzales E, Macari M, Dal Pai V, Oliveira HN. Tipos de fibras no músculo flexor longo do hálux de frangos de corte submetidos ao estresse pelo calor e frio e alimentados em "pair-feeding". Rev Brasil Zootecnia. 2003;32(4):918-25.

43. Dubowitz V, Brooke MH, Neiville H. Muscle biopsy: a modern approach. London: Saunders; 1972.

44. Järvinen MJ, Einola SA, Virtanen EO. Effect of the position of immobilization upon the tensile properties of the rat gastrocnemius muscle. Arch Phys Med Rehabil. 1992;73(3):253-7.

45. Chakravarthy MV, Abraha TW, Schwartz RJ, Fiorotto ML, Booth FW. Insulin-like growth factor-I extend in vitro replicative life span of skeletal muscle satellite cells by enhancing G1/S cell cycle progression via the activation of phosphatidylinositol 3'-kinase/Akt signaling pathway. J Biol Chem. 2000;275(46):35942-52.

46. Kourtidou-Papadeli C, Kyparos A, Albani M, Frossinis A, Papdelis CL, Bamidis P, et al. Electrophysiological, histochemical, and hormonal adaptation of rat muscle after prolonged hindlimb suspension. Acta Astronaut. 2004;54(10):737-47.

47. Chingui LJ, Braquinho RP, Severi MTM, Silva CA. Comportamento quimiometabólico do músculo sóleo na fase aguda da imobilização articular. Fisioter Pesqui. 2008;15(2):194-9.

48. Mayer WP. Características estruturais, ultra-estruturais e morfoquantitativas dos músculos tibial anterior e sóleo de ratos jovens submetidos à imobilização da articulação talocrural [dissertação]. São Carlos: Universidade Estadual de São Paulo; 2008.

49. Järvinen TA, Józsa L, Kannus P, Järvinen TL. Organization and distribution of intramuscular connective tissue. J Muscle Res Cell Motil. 2002;23(3):245-54.

50. Itai Y, Kariya Y, Hoshino Y. Morphological changes in rat hindlimb muscle fibres during recovery from disuse atrophy. Acta Physiol Scand. 2004;181(2):217-24.

Received: 03/26/2013

Recebido: 26/03/2013

Approved: 07/15/2014

Aprovado: $15 / 07 / 2014$ 